\title{
LETTER
}

\section{Sepsis hysteria: facts versus fiction}

\author{
Konrad Reinhart ${ }^{1,2,3^{*}}$, R. D. Daniels ${ }^{4}$, D. Schwarzkopf ${ }^{3}$ and N. Kissoon ${ }^{5}$
}

(c) 2020 The Author(s)

Dear Editor,

"Sepsis hysteria: excess hype and unrealistic expectations" was the title of a recent correspondence to The Lancet by Singer et al. [1]. Their opinion piece comprises claims which are at odds with the available scientific evidence on the burden of sepsis and the effectiveness of efforts to improve the quality of sepsis care. Contrary to the fact that sepsis-related deaths account for $19.7 \%$ of global deaths $(80 \%$ of which occur in low and middle income countries (LIMCs)) [2], the authors state "Sepsis ...only develops in a tiny minority of patients".

Additionally, recent studies from high-income countries (HICs) suggest considerable underreporting, with only between 15 and $50 \%$ of clinically suspected sepsis cases being coded in the International Classification System of Diseases (ICD) [3, 4]. Singer et al. postulate that HICs overestimate incidence, blaming financial incentives and "pressure groups" in countries like the USA and UK for annual relative increases of between 5 and 15\%.

Indeed, Rhee et al. [3] found a $10 \%$ relative annual increase in US (ICD 9-based) sepsis incidence between 2009 and 2014 from 1.4 to $2.5 \%$, but showed electronic health record data analysis-based incidence to be stable at around 6\% of hospitalizations, or 517 episodes per 100,000 population. Sweden has until very recently seen neither performance incentives nor public awareness initiatives, yet a recent health record study suggests population sepsis incidence at around 700 per 100,000 [4].

The authors claim that most sepsis deaths occur among frail elderly patients. They state that in England "approximately 150 sepsis-related deaths occur annually in children aged 0-18 years: a hospital mortality of $0.075 \%$ ". This differs substantially from the hospital mortality rates

\footnotetext{
*Correspondence: konrad.reinhart@charite.de

${ }^{1}$ Department of Anesthesiology and Operative Intensive Care Medicine (CCM, CVK), Charité Universitätsmedizin Berlin, Corporate Member of Freie Universität Berlin, Humboldt-Universität zu Berlin, Berlin, Germany Full author information is available at the end of the article
}

among children under 5 years reported for New York State (11.8\%) [5] and Germany (17.2\%) [6]. Every year, 2 million neonates and children under 5 die with sepsis worldwide [7], with mortality at $19 \%$ in HICs and $32 \%$ in LMICs [8, 9]. Indeed, the Institute for Health Metrics and Evaluation estimated that 25 million children developed sepsis in 2017 [2]. In the UK alone, NHS Digital Hospital Episodes Statistics indicated 350,000 episodes of sepsis in 2017-2018, of which 38,000 were in children under 5 [10].

Are media and patient advocacy groups "creating a distorted picture of sepsis epidemiology and unrealistic expectations of outcomes"? No, but we accept that we don't truly understand the burden of this prevalent condition, and urgently call on governments to create surveillance systems to improve our understanding.

The high incidence of frailty and severe comorbidities makes most sepsis-related deaths neither attributable to sepsis, nor preventable.

The authors cite a US study which showed that only $12 \%$ of sepsis-related deaths were preventable, examining the deaths of just 300 patients of whom a surprisingly high $40.3 \%$ had hospice-qualifying conditions [11]. This patient population is not representative of hospitaltreated patients with sepsis in HICs, and even less so for sepsis patients in LMICs. According to the national ICU registry in England, which is not prone to billing incentives or coding changes, hospital mortality for sepsis decreased between 2000 and 2012 from 45.5 to 32.1\% [12]. Over a ten-year period, although the age of patients with sepsis admitted to European ICUs increased by 2 years, the odds of ICU mortality decreased [13]. This increase in survival observed in other countries perhaps most markedly Australia, brings into question whether we need to accept death from infection or sepsis as inevitable. 
The evidence base [behind Quality Improvement (QI) and timely antibiotic administration] is underwhelming and openly challenged.

The survival benefit of QI has been demonstrated by a meta-analysis of 48 trials [14], and by prospective trials in many countries. Indeed, state-mandated protocolized sepsis care in New York resulted in decreased mortality compared to control states [15]. As depicted in Tab. 1 , the evidence certainly supports time-dependent survival with early antimicrobials, both in secondary analysis of routine data [16-18] and large prospective studies $[19,20]$. Early antimicrobials appear to matter in patients with or without septic shock [20], and delays appear to increase transition from sepsis to septic shock $(\mathrm{OR}=1.08$ per hour) [18]. The rapid administration of antimicrobials should not be limited to "the rare cases of severe infection (e.g. in patients with shock)", but to any patients with infection and signs of acute organ dysfunction.

Despite concerns, there are no published data demonstrating harm with early antibiotics in patients with or without sepsis. Early recognition and prompt antibiotic administration remain the mainstay of care in adults and children. Improved awareness and earlier recognition, tempered by judicious application of diagnostic criteria, save lives. Late presentations to non-resilient healthcare systems are rife in resource-limited settings, but also occur in some disadvantaged populations in HICs.

As has been pointed out [21] the same data source on which Singer based the assertion that sepsis incentives have doubled antimicrobial consumption in Emergency Departments show total hospital consumption of antibiotics to have remained static. We're unable to find evidence linking sepsis improvement programs to antimicrobial resistance. In 2015, Ireland implemented its
National Clinical Guideline and commenced annual publication of National Sepsis Outcome Reports [22]. Antimicrobial usage has not increased, and no adverse impact on multi-drug resistant organism incidence has been observed, while mortality has decreased by $4.7 \%$.

Nevertheless, antimicrobial resistance (AMR) remains a major problem. There is an increasing body of evidence that the use of biomarkers may help prevent inappropriate use of antimicrobials and may improve survival [23, 24]. Furthermore, it is likely that biomarkers and molecular diagnostic techniques will help develop a better understanding of individuals' immune status and prognosis related to both host and pathogen. This may not only contribute to the development of novel immunomodulatory therapies, but also to prevent futile therapy.

Of course "a balanced strategy must be delivered in policy, public messaging, and frontline care". However, the current evidence in published literature overwhelmingly supports treating sepsis as an emergency without any unnecessary delay. Also a report by the National Confidential Enquiry into Patient Outcome and Death (NCEPOD) on the process of care received by patients with sepsis in UK concluded that "Sepsis is a major cause of avoidable mortality and morbidity", because, in a significant number of patients, outcome was affected by delays in antimicrobial and source control [25]. Any discussion about sepsis initiatives that ignores the issue of AMR is counterproductive. Both in concert with other infection prevention strategies should be the foundation of public health strategies. Vulnerable patients with sepsis require concerted global efforts between academics, clinicians, commissioners and policy makers to obtain robust data around the burden of sepsis through analysis of clinical data and point prevalence studies. The huge burden of

Table 1 Effects of time of beginning of antimicrobial therapy on mortality in patients with severe sepsis including septic shock

\begin{tabular}{|c|c|c|c|c|c|}
\hline Study & Type of data & Patients & $\begin{array}{l}\text { Starting point for measuring } \\
\text { time to AT }\end{array}$ & $N$ & $\begin{array}{l}\text { Effect on mortality }{ }^{\mathrm{a}} \text { per hour } \\
\text { delay of AT }\end{array}$ \\
\hline Liu et al. [16] & Medical record data & ED treated & ED registration & 35,000 & $0.3 \%(\mathrm{Cl} 0.01-0.6 \%)$ \\
\hline \multirow[t]{2}{*}{ Seymour et al. [17] } & $\begin{array}{l}\text { Secondary analysis of mandated } \\
\text { sepsis reporting }\end{array}$ & ED treated & Initiation of 3 h-bundle & 49,331 & $\begin{array}{l}\mathrm{OR}=1.04(1.03-1.06) ; \sim 0.8 \% \\
\text { increase }^{c}\end{array}$ \\
\hline & & ED treated & ED registration & 49,331 & $\mathrm{OR}=1.04(1.02-1.05)$ \\
\hline Whiles et al. [18] & Medical record data & ED treated & ED triage & 3929 & $\mathrm{OR}=1.05(1.03-1.07)$ \\
\hline Ferrer et al. [20] & $\begin{array}{l}\text { Secondary analysis of prospective } \\
\text { trial data }\end{array}$ & ICU treated & $\begin{array}{l}\text { First presentation of symptoms of } \\
\text { organ dysfunction }\end{array}$ & 17,990 & $\sim 1.4 \%$ increase $^{b}$ \\
\hline Bloos et al. [19] & $\begin{array}{l}\text { Secondary analysis of prospective } \\
\text { trial data }\end{array}$ & ICU treated & $\begin{array}{l}\text { First presentation of symptoms of } \\
\text { organ dysfunction }\end{array}$ & 3870 & $\mathrm{OR}=1.02(\mathrm{Cl} 1.01,1.03)$ \\
\hline
\end{tabular}

$A T$ antimicrobial therapy, ICU intensive care unit, ED emergency department

a Effects on 28-day mortality (Bloos et al.) or hospital mortality (all other studies)

b Mean increase per hour obtained from Fig. 2 in Ferrer et al.

c Mean increase per hour obtained from Fig. 3B in Seymour et al. 
sepsis demands that, from a humanitarian and scientific perspective, there is no alternative but to harness our resources and work responsibly and collaboratively.

The actions undertaken in the USA and England have become examples of sound public health policy. The benefits goes beyond improvement of care but serves to encourage other countries to integrate sepsis in national health strategies-most recently, the Ministries of Health in France, Sweden and Australia.

Addressing the burden of sepsis and showing improving trends by increasing awareness and quality improvement initiatives by high profile and esteemed sepsis experts provides a counterbalance for all those who are still ignoring this global health priority.

We believe that our patients deserve more from us than this unfortunate level of polarization. Today, tens of thousands of patients will die or be disabled by sepsis globally. This is not hype, this is a tragedy.

\footnotetext{
Author details

1 Department of Anesthesiology and Operative Intensive Care Medicine (CCM, (VK), Charité Universitätsmedizin Berlin, Corporate Member of Freie Universität Berlin, Humboldt-Universität zu Berlin, Berlin, Germany. ${ }^{2}$ Berlin Institute of Health, Campus Virchow-Klinikum, Berlin, Germany. ${ }^{3}$ Institute of Infectious Diseases and Infection Control, Jena University Hospital, Jena, Germany. ${ }^{4}$ University Hospitals Birmingham NHS Foundation Trust, Birmingham, UK. ${ }^{5}$ Department of Pediatrics, Emergency Medicine and Critical Care, University of British Columbia, Vancouver, Canada.
}

\section{Acknowledgements}

Open Access funding provided by Projekt DEAL.

\section{Compliance with ethical standards}

\section{Conflicts of interest}

The authors declare that they have no conflict of interest.

\section{Open Access}

This article is licensed under a Creative Commons Attribution-NonCommercial 4.0 International License, which permits any non-commercial use, sharing, adaptation, distribution and reproduction in any medium or format, as long as you give appropriate credit to the original author(s) and the source, provide a link to the Creative Commons licence, and indicate if changes were made. The images or other third party material in this article are included in the article's Creative Commons licence, unless indicated otherwise in a credit line to the material. If material is not included in the article's Creative Commons licence and your intended use is not permitted by statutory regulation or exceeds the permitted use, you will need to obtain permission directly from the copyright holder.To view a copy of this licence, visit http://creativecommons.org/licen ses/by-nc/4.0/

\section{Publisher's Note}

Springer Nature remains neutral with regard to jurisdictional claims in published maps and institutional affiliations.

\section{Accepted: 5 March 2020}

Published online: 4 May 2020

\section{References}

1. Singer M, Inada-Kim M, Shankar-Hari M (2019) Sepsis hysteria: excess hype and unrealistic expectations. Lancet 394:1513-1514
2. Rudd KE, Johnson SC, Agesa KM, Shackelford KA, Tsoi D, Kievlan DR, Colombara DV, Ikuta KS, Kissoon N, Finfer S, Fleischmann-Struzek C, Machado FR, Reinhart KK, Rowan K, Seymour CW, Watson RS, West TE, Marinho F, Hay SI, Lozano R, Lopez AD, Angus DC, Murray CJL, Naghavi M (2020) Global, regional, and national sepsis incidence and mortality, 1990-2017: analysis for the Global Burden of Disease Study. Lancet 395:200-211

3. Rhee C, Dantes R, Epstein L et al (2017) Incidence and trends of sepsis in us hospitals using clinical vs claims data, 2009-2014. JAMA 318:1241-1249

4. Mellhammar L, Wullt S, Lindberg Å, Lanbeck P, Christensson B, Linder A (2016) Sepsis incidence: a population-based study. Open Forum Infect Dis 3:ofw207

5. Evans IVR, Phillips GS, Alpern ER, Angus DC, Friedrich ME, Kissoon N, Lemeshow S, Levy MM, Parker MM, Terry KM, Watson RS, Weiss SL, Zimmerman J, Seymour CW (2018) Association between the New York sepsis care mandate and in-hospital mortality for pediatric sepsis. JAMA 320:358-367

6. Fleischmann-Struzek C, Mikolajetz A, Schwarzkopf D, Cohen J, Hartog CS, Pletz M, Gastmeier P, Reinhart K (2019) Challenges in assessing the burden of sepsis and understanding the inequalities of sepsis outcomes between National Health Systems: secular trends in sepsis and infection incidence and mortality in Germany. Intensive Care Med 44(11):18261835. https://doi.org/10.1007/s00134-018-5377-4

7. Liu L, Oza S, Hogan D, Perin J, Rudan I, Lawn JE, Cousens S, Mathers C, Black RE (2015) Global, regional, and national causes of child mortality in 2000-13, with projections to inform post-2015 priorities: an updated systematic analysis. Lancet 385:430-440

8. Tan B, Wong JJ-M, Sultana R, Koh JCJW, Jit M, Mok YH, Lee JH (2019) Global case-fatality rates in pediatric severe sepsis and septic shock: a systematic review and meta-analysis. JAMA Pediatr 173:352-362

9. Farris RWD, Weiss NS, Zimmerman JJ (2013) Functional outcomes in pediatric severe sepsis: further analysis of the researching severe sepsis and organ dysfunction in children: a global perspective trial. Pediatr Crit Care Med 14:835-842

10. NHS Digital (2019) Discharges for sepsis broken down by age, 2015-16 to 2017-18. https://digital.nhs.uk/data-and-information/find-data-and-publi cations/supplementary-information/2019-supplementary-informatio n-files/discharges-for-sepsis-broken-down-by-age-2015-16-to-2017-18. Accessed 25 Feb 2020

11. Rhee C, Jones TM, Hamad Y, Pande A, Varon J, O'Brien C, Anderson DJ, Warren DK, Dantes RB, Epstein L, Klompas M, for the Centers for Disease C, Prevention Prevention Epicenters P (2019) Prevalence, underlying causes, and preventability of sepsis-associated mortality in US acute care hospitals. JAMA Netw Open 2:e187571

12. Shankar-Hari M, Harrison DA, Rubenfeld GD, Rowan K (2017) Epidemiology of sepsis and septic shock in critical care units: comparison between sepsis-2 and sepsis-3 populations using a national critical care database. Br J Anaesth 119:626-636

13. Vincent J-L, Lefrant J-Y, Kotfis K, Nanchal R, Martin-Loeches I, Wittebole X, Sakka SG, Pickkers P, Moreno R, Sakr Y, Pavlik P, Manak J, Kieslichova E, Turek R, Fischer M, Valkova R, Dadak L, Dostal P, Malaska J, Hajek R, Židková A, Lavicka P, Medve L, Sarkany A, Kremer I, Marjanek Z, Tamasi P, Kolbusz J, Kübler A, Mielczarek B, Mikaszewska-Sokolewicz M, Kotfis K, Tamowicz B, Sulkowski W, Smuszkiewicz P, Pihowicz A, Trejnowska E, Hagau N, Filipescu D, Droc G, Lupu M, Nica A, Stoica R, Tomescu D, Constantinescu D, Valcoreanu Zbaganu G, Slavcovici A, Soskic L, Palibrk I, Jankovic R, Jovanovic B, Pandurovic M, Bumbasirevic V, Uljarevic B, Surbatovic M, Ladjevic N, Slobodianiuk G, Sobona V, Cikova A, Gebhardtova A, Cohen J, Sold O, Urbanek P, Schlieber J, Reisinger J, Auer J, Hartjes A, Lerche A, Janous T, Kink E, Krahulec W, Smolle K, Van Der Schueren M, Thibo P, Vanhoof M, Ahmet I, Philippe G, Dufaye P, Jacobs O, Fraipont V, Biston P, Dive A, Bouckaert Y, Gilbert E, Gressens B, Pinck E, Collin V, Vincent JL, De Waele J, Rimachi R, Gusu D, De Decker K, Mandianga K, Heytens L, Wittebole X, Herbert S, Olivier V, Vandenheede W, Rogiers P, Kolodzeike P, Kruse M, Andersen T, Harjola V, Saarinen K, Leone M, Durocher A, Moulront S, Lepape A, Losser M, Cabaret P, Kalaitzis E, Zogheib E, Charve P, Francois B, Lefrant JY, Beilouny B, Forceville X, Misset B, Jacobs F, Bernard F, Payen D, Wynckel A, Castelain V, Faure A, Lavagne P, Thierry L, Moussa M, VieillardBaron A, Durand M, Gainnier M, Ichai C, Arens S, Hoffmann C, Kaffarnik M, Scharnofske C, Voigt I, Peckelsen C, Weber M, Gille J, Lange A, Schoser G, 
Sablotzki A, Jaschinski U, Bluethgen A, Vogel F, Tscheu A, Fuchs T, Wattenberg M, Helmes T, Scieszka S, Heintz M, Sakka S, Kohler J, Fiedler F, Danz M, Sakr Y, Riessen R, Kerz T, Kersten A, Tacke F, Marx G, Volkert T, Schmutz A, Nierhaus A, Kluge S, Abel P, Janosi R, Utzolino S, Bracht H, Toussaint S, Giannakou Peftoulidou M, Myrianthefs P, Armaganidis A, Routsi C, Xini A, Mouloudi E, Kokoris I, Kyriazopoulos G, Vlachos S, Lavrentieva A, Partala P, Nakos G, Barry J, O'Leary R, Motherway C, Faheem M, Dunne E, Donnelly M, Konrad T, Bonora E, Achilli C, Rossi S, Castiglione G, Peris A, Albanese D, Stocchetti N, Citerio G, Mozzoni L, Sisillo E, De Negri P, Savioli M, Vecchiarelli P, Puflea F, Stankovic V, Minoja G, Montibeller S, Calligaro P, Sorrentino R, Feri M, Zambon M, Colombaroli E, Giarratano A, Pellis T, Capra C, Antonelli M, Gullo A, Chelazzi C, De Capraris A, Patroniti N, Girardis M, Franchi F, Berlot G, Ponssen H, Ten Cate J, Bormans L, Husada S, Buise M, Van Der Hoven B, Reidinga A, Kuiper M, Pickkers P, Kluge G, Den Boer S, Kesecioglu J, Van Leeuwen H, Flaatten H, Mo S, Branco V, Rua F, Lafuente E, Sousa M, Catorze N, Barros M, Pereira L, Vintém De Oliveira A, Gomes J, Gaspar I, Pereira M, Cymbron M, Dias A, Almeida E, Beirao S, Serra I, Ribeiro R, Povoa P, Faria F, Costa-E-Silva Z, Nóbrega J, Fernandes F, Gabriel J, Voga G, Rupnik E, Kosec L, Kerin Povšic M, Osojnik I, Tomic V, Sinkovic A, González J, Zavala E, Pérez Valenzuela J, Marina L, Vidal-Cortés P, Posada P, Ignacio Martin-Loeches A, Muñoz Guillén N, Palomar M, Sole-Violan J, Torres A, Gonzalez Gallego M, Aguilar G, Montoiro Allué R, Argüeso M, Parejo M, Palomo Navarro M, Jose A, Nin N, Alvarez Lerma F, Martinez O, Tenza Lozano E, Arenal López S, Perez Granda M, Moreno S, Llubia C, De La Fuente Martos C, Gonzalez-Arenas P, Llamas Fernández N, Gil Rueda B, Estruch Pons I, Cruza N, on behalf of the Icon Soap investigators (2018) Comparison of European ICU patients in 2012 (ICON) versus 2002 (SOAP). Intensive Care Med 44:337-344

14. Damiani E, Donati A, Serafini G, Rinaldi L, Adrario E, Pelaia P, Busani S, Girardis M (2015) Effect of performance improvement programs on compliance with sepsis bundles and mortality: a systematic review and meta-analysis of observational studies. PLoS ONE 10:e0125827

15. Kahn JM, Davis BS, Yabes JG, Chang C-CH, Chong DH, Hershey TB, Martsolf GR, Angus DC (2019) Association between state-mandated protocolized sepsis care and in-hospital mortality among adults with sepsis. JAMA 322:240-250

16. Liu VX, Fielding-Singh V, Greene JD, Baker JM, Iwashyna TJ, Bhattacharya J, Escobar GJ (2017) The timing of early antibiotics and hospital mortality in sepsis. Am J Respir Crit Care Med 196:856-863

17. Seymour CW, Gesten F, Prescott HC, Friedrich ME, Iwashyna TJ, Phillips GS, Lemeshow S, Osborn T, Terry KM, Levy MM (2017) Time to treatment and mortality during mandated emergency care for sepsis. N Engl J Med $376: 2235-2244$
18. Whiles BB, Deis AS, Simpson SQ (2017) Increased time to initial antimicrobial administration is associated with progression to septic shock in severe sepsis patients. Crit Care Med 45:623-629

19. Bloos F, Rüddel H, Thomas-Rüddel D, Schwarzkopf D, Pausch C, Harbarth S, Schreiber T, Gründling M, Marshall J, Simon P, Levy MM, Weiss M, Weyland A, Gerlach H, Schürholz T, Engel C, Matthäus-Krämer C, Scheer C, Bach F, Riessen R, Poidinger B, Dey K, Weiler N, Meier-Hellmann A, Häberle HH, Wöbker G, Kaisers UX, Reinhart K (2017) Effect of a multifaceted educational intervention for anti-infectious measures on sepsis mortality: a cluster randomized trial. Intensive Care Med 43:1602-1612

20. Ferrer R, Martin-Loeches I, Phillips G, Osborn TM, Townsend S, Dellinger RP, Artigas A, Schorr C, Levy MM (2014) Empiric antibiotic treatment reduces mortality in severe sepsis and septic shock from the first hour: results from a guideline-based performance improvement program. Crit Care Med 42:1749-1755

21. Nutbeam T, Daniels R (2019) Sepsis and antibiotic mindfulness: an alternative to hype and hyperbole. https://sepsistrust.org/professional-resou rces/clinical/. Accessed 2 Mar 2020

22. Health Service Executive (2019) National Sepsis Report 2018. https:// www.hse.ie/eng/about/who/cspd/ncps/sepsis/resources/national-sepsi s-report-2018.pdf. Accessed 25 Feb 2020

23. Schuetz P, Wirz Y, Sager R, Christ-Crain M, Stolz D, Tamm M, Bouadma L, Luyt CE, Wolff M, Chastre J, Tubach F, Kristoffersen KB, Burkhardt O, Welte T, Schroeder S, Nobre V, Wei L, Bucher HC, Annane D, Reinhart K, Falsey AR, Branche A, Damas P, Nijsten M, de Lange DW, Deliberato RO, Oliveira CF, Maravić-Stojković V, Verduri A, Beghé B, Cao B, Shehabi Y, Jensen J-US, Corti C, van Oers JAH, Beishuizen A, Girbes ARJ, de Jong E, Briel M, Mueller $B$ (2018) Effect of procalcitonin-guided antibiotic treatment on mortality in acute respiratory infections: a patient level meta-analysis. Lancet Infect Dis 18:95-107

24. de Jong E, van Oers JA, Beishuizen A, Vos P, Vermeijden WJ, Haas LE, Loef BG, Dormans T, van Melsen GC, Kluiters YC, Kemperman H, van den Elsen MJ, Schouten JA, Streefkerk JO, Krabbe HG, Kieft H, Kluge GH, van Dam VC, van Pelt J, Bormans L, Otten MB, Reidinga AC, Endeman H, Twisk $J W$, van de Garde EMW, de Smet AMGA, Kesecioglu J, Girbes AR, Nijsten MW, de Lange D (2016) Efficacy and safety of procalcitonin guidance in reducing the duration of antibiotic treatment in critically ill patients: a randomised, controlled, open-label trial. Lancet Infect Dis 16:819-827

25. Goodwin APL, Srivastava V, Shotton H, Protopapa K, Butt A, Mason M (2015) Just say sepsis! A review of the process of care received by patients with sepsis. http://www.ncepod.org.uk/2015report2/downloads/JustS aySepsis_FullReport.pdf. Accessed 25 Feb 2020 